\title{
EMBRIOLOGY OF DERMOID CYSTS WITH NEURO-ECTODERMAL CONTENT
}

\author{
Dimo S. Krastev ${ }^{1}$, Ina Filipova ${ }^{2}$ \\ 1) College of Medicine "J. Filaretova", Medical University - Sofia, \\ 2) Second Municipal Hospital for Obstetrics and Gynecology Sheynovo PLS, \\ Sofia, Bulgaria.
}

\section{SUMMARY:}

Each of the tissues that form the human body is made up of cells and intercellular substance. Tissues do not exist in isolation, but through each other metabolic relations build organs and systems of the body during ontogeny.

During embryonic development tissues take certain place but sometimes they can be combined in different proportions and in different parts of the body. Thus, the mix of tissue formed as such derived from different embryonic structures serve to store a dermoid cysts $[1,2$, $3,4]$.

Key words: embryonic development, dermoid cysts, nervous tissue

\section{INTRODUCTION:}

Dermoid cysts are benign germ - cell tumors containing a combination of different types of tissues, and often parts or whole bodies. We present a case of ovarian teratoma with contents of neuro-ectodermal origin with extensive nervous tissue sections $[5,6]$.

These findings were observed in patomorpfological examination of sustained histological preparation of operative laparoscopy of a patient with dermoid cyst [7]. From the ectoderm derived the epidermis of the skin and related structures (glands, hair, nails, the epithelium of the oral and nasal cavities, anal area, external auditory canal, cornea, conjunctiva, parotid and lacrimal glands) central and peripheral nervous system.

The first rudiments of the central nervous system is the appearance in the $18^{\text {th }}$ day of the neural plate in the median sagittal plane of the ectoderm, the primary cranial fossa. Neural plate is made of tall cylindrical cells called neuroephitelian cells or neuroectoderm.

\section{Purpose}

The aim of this study is:

1. Using histological techniques to provide structure dermoid cyst with contents of neuroectodermal origin;

2. With the help of embrional development to be explained the occurrence of nervous tissue and cystic formation.

\section{MATERIALS AND METHODS}

Thru the conduction of the experimental research all the ethical principles were followed, applied by the Medical University - Sofia and the legal requirements to protect human rights.

The procedure for preparation of lasting histological preparations passed by a standard protocol approved by the Department of Anatomy and Histology and consistent with the objective. The pictures of the prepared products are presented in section results.

\section{RESULTS:}

We present light-microscopic features of dermoid cyst with contents of neuro-ectodermal origin.

Description of histological preparations

The outer shell of cystic formation is represented by dense connective tissue with abundant collagen fibers characteristics of soft brain sheat (Fig. 1).

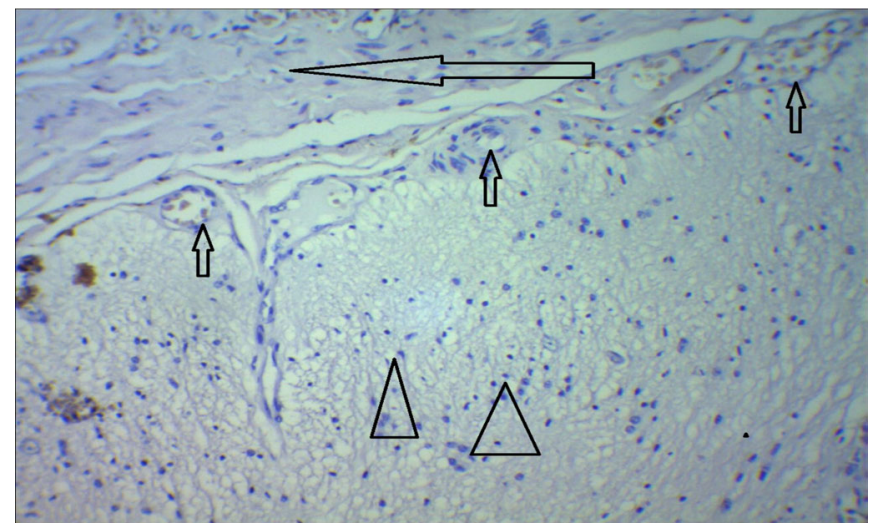

Fig. 1. Connective tissue capsule made up of structure with characteristics of pia mater (large white arrow). The presence of numerous blood vessels on the surface of nerve tissue (small white arrows). Presence of neurons with different forms of perikaryon (arrow heads). HE x 10

The main finding filling the contents of the dermoid cyst is clearly shaped but not completely structured, brain tissue present on (Fig. 1, 2 and 3). 


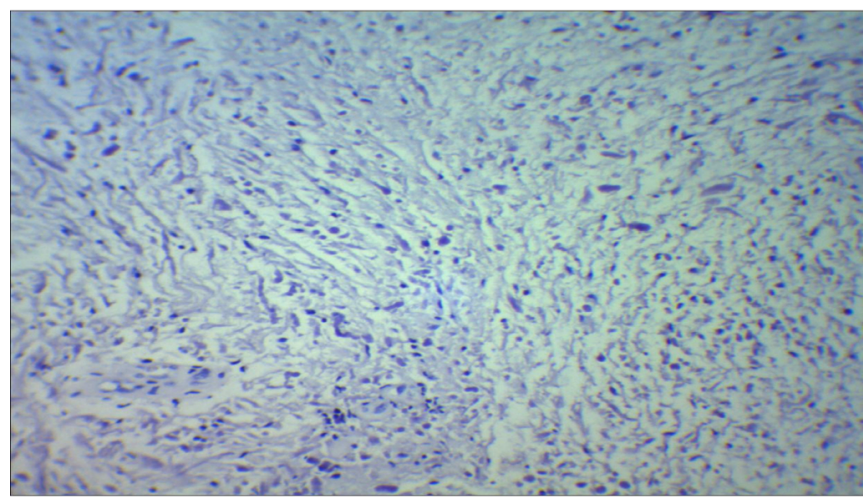

Fig. 2. Histological picture is specific for nervous tissue resembling in structure of the neocortex. At a thorough monitoring, neurons with polymorphic shape and different size are observed. There is no typical sequence of layers creating the telentsephalon. Nissl x 10

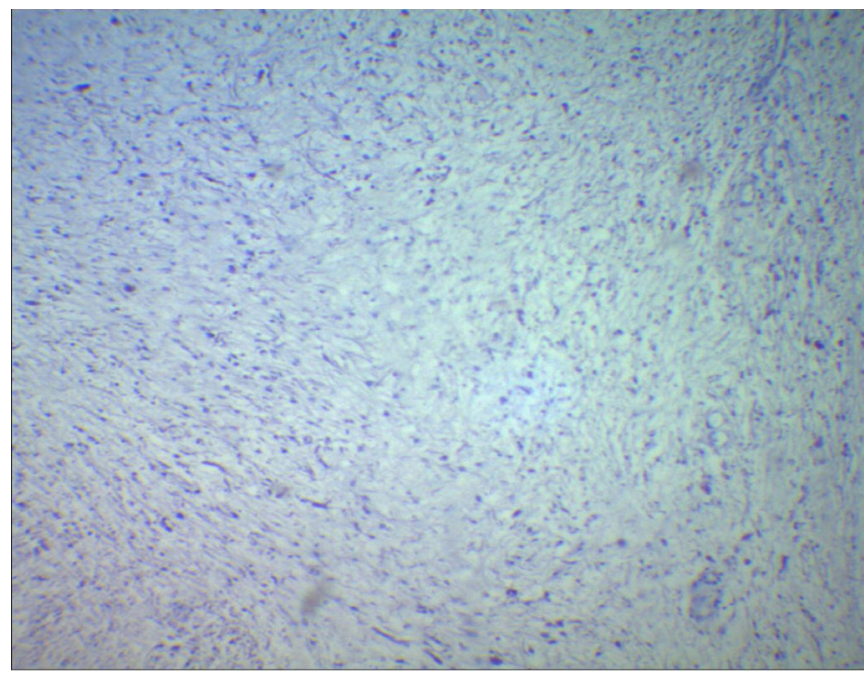

Fig. 3. Nervous tissue is represented by neurons and plentiful of the glia. Between glia neurons vary in shape and size. This finding is demonstrated characteristic of sensory cortex of the brain area. Nissl x 10

\section{DISCUSSION:}

We present findings found in ovarian cystic formation of patient in fertile age removed by operative laparoscopy $[1,8,9]$.

The removed abnormality has been identified histologicaly as a dermoid cyst containing tissues derived from neuro-ectodermal origin. The results of the histology picture of cystic formation revealed extensive areas of brain tissue and the presence of connective tissue capsule with characteristics of pia mater $[5,6]$.

For revealing the essence of dermoid cyst we should emphasize at fetal origins of ectodermal derivatives list, their genesis and their migration.
Nervous tissue is the most complicated and complex system organized in the human body. It is composed of over a trillion nerve cells (neurons) that communicate with each other and coordinate their activities. It controls and integrates the functional activity of organs and systems. Nervous tissue is composed of two principle types of cells - nerve cells or neurons and neuroglial cells or glia Neurons are the basic functional population of cells that are highly specialized to receive and process stimuli and as a nerve impulses to transmit with nerve cells or other cells that perform different functions. To implement impulse transmitting function neurons are organized in a complex and integrated network, building the central and peripheral nervous system.

The second cell population neuroglial cells perform supporting, protective function to the neurons and their ramifications. It is involved in metabolic exchange between the circulatory system and neurons and interferes with the electric influence of nerve impulses conducted through the bodies and growths of the nerve cells.

The size of nerve cells ranged from $4-5$ to $150 \mathrm{Mm}$. The shape is different and varies depending on the number of growths, thus grouping, location and function. Body or perikarion apparently occupies most of the volume of the cell and the nucleus is large, often spherical or ovoid and positioned centrally. The major part of the chromatin is finely dispersed showing its role in the rich synthetic function of cells, smaller cells have a well-developed condensed heterochromatin. In the cytoplasm there is abundance of granular endoplasmic reticulum. Lightmicroscopic underlining basophilia of the reticulum is marked with the classic definition of Nissl cells or granular Nissls.

Human development in the embryonic period involves three main phases, which are interlinked and mutually influenced. The first is the growth that includes division process of of cells and creation of cell products. The second phase is morphogenesis, which involves movement of the cell mass and the complex interactions between them in the formation of organs and systems. The third phase is the differentiation thru which specialized and gradually improved cellular structures involved in the organs and the systems can perform certain functions.

The first rudiment of the central nervous system is the emergence in the $18^{\text {-th }}$ day of the neural plate in the median sagittal plane of the ectoderm, cranial to the primary fossa. Neural plate is made of high cylindrical cells called neuroepithelium cells or commonly neuroectoderm. Cells develop from the caudal-cranial direction. In the fourth week plate bends and transforms into neural tube, which is a precursor in the development of the nervous system. Lateral parts of the neural plate gradually formed nerve comb that separates from the neural tube and differentiate into other neural structures. Nerve plate expands in its cranial part and 
gradually narrows to caudate direction. From its expanded cranial area is developing the main brain-encephalon. Even at this early period of development future major parts of the brain have been identified as front-prosencephalon, middlemesencephalon and rear brains-rhombencephalon.

Cytodiferentiation of neural tube begins in the $24^{\text {th }}$ day, as neurons, glial cells and ependym cells of the central nervous system is differentiated from neuroepithelium located adjacent to the nerve canal. This layer of proliferating cells denote by ventricular layer. First hymns came neuroblasts which migrate peripherally to form a second layer of mantle. These cells produce neurons and gray matter of central neuro system. Their growths form, third marginal layer that builds white matter of C.N.S..

Once production of neuroblasts of neuroepithelium around a central channel are formed glioblasts that differentiate into astrocytes and oligodendrocytes. Last from epithelium are produced ependim cells covering, brain tummy - ventriculi and cerebral spinal canal.

From everything said so far it is clear that finding, we describe is atypical, but it is possible because of the complex migration process in the course of ontogenetic development. Following the migration of neurons in an unusual place away from genetically determined, starts a process of differentiation and development of a structure resembling the sensory area of the cerebral cortex.

\section{CONCLUSIONS}

Embryonic development thru the development of cystic formation are observed structural changes violating the normal morphology of the formation [6], but repeating the embryonic development.of the neuroectoderm.

\section{REFERENCES:}

1. Bolla D, Deseo N, Sturm A, Schoning A, Leimgruber C. Minilaparotomy a good option in specific cases: a case report of bilateral ovarian germ cell tumor Case Rep Obstet Gynecol. 2012; 2012:589568. Epub 2012

Mar 5. [PubMed] [CrossRef]

2. Boufettal H, Ait Idder L, Serbouti S, Mahdaoui S, Noun M, Hermas S, et al. Malignant degeneration of ovarian dermoid cyst. [Article in French] Presse Med. 2013 Feb; 42 (2):232-5. Epub 2012 Apr 4. [PubMed] [CrossRef]

3. Pectasides D, Pectasides E, Kassanos D. Germ cell tumors of the ovary. Cancer Treat Rev. 2008 Aug; 34(5):427-441, Epub 2008 Apr 18.
[PubMed] [CrossRef]

4. Guzel AI, Kuyumcuoglu U, Erdemoglu M. Adnexal masses in postmenopausal and reproductive age women. J Exp Ther Oncol. 2011; 9(2):1679. [PubMed]

5. Filipova I, Krastev D. Mature teratomas (Dermoid cysts) with ectoend neuro - ectoderal content. Zdrave $i$ Nauka, 2012; 2(4):44-49

6. Filipova I, Krastev D. Morphological features of ovarian dermoid cysts containing nervous tissue. Trakia University - Stara Zagora 65 yrs. Medical College Collection of reports, 2012 Oct 19; p123-129

7. Nezhat C, Kotikela S, Mann A,
Hajhosseini B, Veeraswamy A, Lewis M. Familial cystic teratomas: four case reports and review of the literature. $J$ Minim Invasive Gynecol. 2010 Nov;17(6):782-6. [PubMed] [CrossRef]

8. Ozgur T, Atik E, Silfeler DB, Toprak S. Mature cystic teratomas in our series with review of the literature and retrospective analysis. Arch Gynecol Obstet. 2012 Apr; 285(4):1099-1101. Epub 2011 Dec 14. [PubMed] [CrossRef]

9. Sahraoui W, Hajji S, Essefi A, Haouas N, Hmissa S, Bibi M, et al. [Ovary teratoma. Report of 91 cases]. [in French] Tunis Med. 2006 Jun; 84(6): 349-352. [PubMed]

\section{Corresponding author:}

Dimo Stoyanov Krastev, PhD

College of Medicine "Jordanka Filaretova", Medical University-Sofia, Bulgaria. Tel.: +359/2/915 4628 e-mail:dimo_krustev@mail.bg, 